\title{
Utilization of a modified percutaneous nephrostomy tube placement: comparison to standard methodology
}

\author{
L Proklova*, TI Kyrkalova, DE Sablin, MU Yanitskaya \\ From 9th WINFOCUS World Congress on Ultrasound in Emergency and Critical Care \\ Hong Kong. 6-9 November 2013
}

\section{Introduction}

Percutaneous nephrostomy is used for temporary or permanent drainage of an obstructed pelvicalyceal system.

\section{Objective}

The aim of this study is to compare the success rates and complications of the modified and standard technique in percutaneous nephrostomy tube placement (PCN) in dilated and non-dilated systems in children.

\section{Patients and methods}

We retrospectively analysed 47 emergent percutaneous nephrostomies in dilated an non-dilated systems in 35 patients from 2001 to 2012 (range 1 months - 14 years), using standard or modified technique. "Standard" technique of PCN was performed using the Seldinger or one-step techniques in dilated and non-dilated systems under Ulrasound control. "Modified" technique was performed using Seldinger technique with insertion additional needle in pelvicalyceal system, and both the Ultrasound and Fluoroscopy control was used. Percutaneous nephrostomy was considered successful if catheter was placed in renal pelvis and drained urine spontaneously.

\section{Results}

The success rates in cases with modified technique was $95.7 \%$, and $80.7 \%$, in those where standard technique was used. No complications were registered.

\section{Conclusion}

Modified technique in percutaneous nephrostomy using additional needle and both the Ultrasound and Fluoroscopy control is successful and safe methodology in the temporary or permanent treatment of obstructed pelvicalyceal system in comparison with standard technique.

Published: 31 January 2014

doi:10.1186/2036-7902-6-S1-A19

Cite this article as: Proklova et al:: Utilization of a modified

percutaneous nephrostomy tube placement: comparison to standard methodology. Critical Ultrasound Journal 2014 6(Suppl 1):A19.
Submit your manuscript to a SpringerOpen ${ }^{\circ}$ journal and benefit from:

- Convenient online submission

- Rigorous peer review

- Immediate publication on acceptance

- Open access: articles freely available online

- High visibility within the field

- Retaining the copyright to your article
Federation

SpringerOpen ${ }^{\odot}$ (c) 2014 Proklova et al; licensee Spinger. This is an Open Access article distributed under the terms of the Creative Commons Attribution License (http://creativecommons.org/licenses/by/2.0), which permits unrestricted use, distribution, and reproduction in any medium, provided the original work is properly cited. The Creative Commons Public Domain Dedication waiver (http:// creativecommons.org/publicdomain/zero/1.0/) applies to the data made available in this article, unless otherwise stated. 